like some humans, he seemed more proud than any of the others when at last he landed safely.

Following the flight from the nest there is a day or two of anxiety until the wings are strong and sure enough to carry their owner quickly from the path of a sneaking cat. Last year I helped our neighbor stand guard, sometimes chasing a fourlegged enemy away, sometimes chasing the young Robin up to a higher perch when he thought, in his ignorance, safety lay on the ground. I am sure Mrs. Robin will expect my help again this year for she has her family in a branch just outside my bedroom window where she knows I can help her keep watch.

\section{Bluebird Arrives April 10}

M. M. NAIR, Grande Prairie, Alta.

I doubt if the word that I saw a Bluebird on April 10th this year is any record but with the cold and backward Spring we are experiencing in our Peace River country this year, it may be so. Yesterday, April 18 , on a drive of about ten miles we saw such a great number of owls, seemingly of all sizes and kinds but the most outstanding was a Snowy, sitting in a particularly snowed over world like a slab of snow, until the movement of his head made us realize it was a bird.

\section{New Historical Society}

Our best wishes are extended to the new club recently organized at Spy Hill. The club has adopted the name of "The Wolverine Hobby and Historical Society." Members of the group from Tantallon, Welby, Hazelcliffe, Gerald, Russell and Spy Hill are planning an active program.

President is Mr. W. J. McDonald of Yorkton; vice-president, Mrs. F. C. Dafoe, Spy Hill; and secretary-treasurer, A. M. Provick of Hazelcliffe. This group was formed to foster hobbies and preserve historical data. The name "Wolverine" was chosen in that it was the name of a hill now known as Spy Hill. It is also the name of creeks in Manitoba and Saskatchewan with historical significance.

\section{Nature Briefs}

On April 27 we counted thirty-five deer grazing in the field near the house. They show very little fear of us - perhaps because we do not allow any shooting on this farm.

- Mrs. Robert Greenbank, Kelso

I hope the name of the "Blue Jay" will not be changed but I think it might be designated as Western Canada's Nature Magazine, rather than Saskatchewan's, since Manitoba, Alberta and British Columbia letters are not lacking in the issues, I have noticed.

-M. M. Nair, Grande Prairie, Alta.

Stuart J. Francis, of Sprucedale Farm, Torch River, applied for a bird-banding permit this past winter. Assisted by his brother, Stanley, and his father, C. Stuart Francis, he made the necessary trapping equipment. They trapped and banded 100 birds the first day. Perhaps this is a record for the first day of banding.

Congratulations, Stuart! I'm sure the readers will wish you the best of luck in your new and interesting hobby.

- Billy Matthews, Nipawin, Sask.

The "Blue Jay" is too good to miss. Its informative and cheery articles give me happy moments. It is good to read what others are doing who have the same interests as I ... My first crow was heard on the 15th of March, and that one signal has given me the spring fever to study migrants as they pass through this central fly-way, the Red River Valley. If all other bird watchers are as eager as I am, not much will be missed.

- Mrs. Bill Adams, Winnipeg

A scout swallow usually pays us a visit in March. For several years it has been on the 28th - my wife's birthday. Last year it was the 29th. There is no mistake about it, as it comes inside the barn where it usually nests, and perches on an iron hook near the door. I have been able to get a good look at it from a distance of a few feet. It only comes around noon and is away. Then we see it no more until they come to stay.

-Walter Lunn, Brombury, Sask. 